\title{
PENGARUH KONSENTRASI ETANOL TERHADAP AKTIVITAS ANTIOKSIDAN EKSTRAK DAUN SIRIH MERAH (Piper crocatum Ruitz \& Pav) MENGGUNAKAN METODE MICROWAVE ASSISTED EXTRACTION (MAE)
}

\section{Effect of Ethanol Concentration of Antioxidant Activity Red Betel Leaves Extract (Piper crocatum Ruitz \& Pav) with Microwave Assisted Extraction (MAE)}

\author{
I Gede Tirta Yasa ${ }^{1)}$, Nengah Kencana Putra' ${ }^{2)}$, Anak Agung Istri Sri Wiadnyani ${ }^{2)}$ \\ ${ }^{1}$ Mahasiswa Program Studi Ilmu dan Teknologi Pangan, Fakultas Teknologi Pertanian, Unud \\ ${ }^{2}$ Dosen Program Studi Ilmu dan Teknologi Pangan, Fakultas Teknologi Pertanian, Unud \\ Kampus Bukit Jimbaran, Badung-Bali
}

\begin{abstract}
This study was conducted to determine the effect of ethanol concentration on antioxidant activity and to obtain the highest antioxidant activity in red betel leaves extract using the MAE method. The experimental design used in this study was a completely randomized design (CRD) with an ethanol concentration treatment consisting of five levels, namely $50 \%, 60 \%, 70 \%, 80 \%$, and $90 \%$. All treatments were repeated three times to obtain 15 experimental units. The data obtained were analyzed by variance and if the treatment had significant effect followed by Duncan test. Treatment of ethanol concentration had a very significant effect $(\mathrm{P}<0.01)$ on yield, total phenol, total flavonoids, and antioxidant activity. The results showed that $90 \%$ ethanol concentration was the best treatment which produced a yield of $25.17 \%$, total phenol $106.00 \mathrm{mg} \mathrm{GAE} / \mathrm{g}$ extract, total flavonoids $46.98 \mathrm{mg}$ QE / g and antioxidant activity based on IC50 at $81.61 \mathrm{ppm}$.

Keywords : red betel leaves, ethanol, MAE, antioxidant activity.
\end{abstract}

\section{PENDAHULUAN}

Daun sirih merah (Piper crocatum Ruitz \& Pav) memiliki bentuk eksotik dengan permukaan daunnya bergelombang disertai warna daun hijau, pink, dan perak pada permukaan atas daun, serta warna merah keunguan pada permukaan bawah daun sehingga menarik perhatian banyak orang. Tanaman ini juga mendapat perhatian khusus dari kalangan herbalis karena banyak dimanfaatkan sebagai tanaman obat-obatan. Salah satu senyawa kimia yang bermanfaat dalam sirih merah adalah flavonoid yang berfungsi sebagai antioksidan (Kanifah dkk., 2015). Sudewo (2005) melaporkan juga bahwa selain flavonoid ada senyawa fitokimia lain yang terkandung dalam daun sirih merah yakni alkoloid, saponin, tannin, dan polifenol. Sulistiyani dkk. (2007) melaporkan juga bahwa daun sirih merah memiliki kandungan kimia lainnya yaitu hidroksikavikol, kavikol, kavibetol, karvakrol, eugenol, p-simen, sineol, kariofilen, kadimen estragol, terpenena, dan fenil propanoid.
Kandungan kimia dalam suatu bahan dapat diperoleh dengan melakukan proses ekstraksi yang bertujuan mengeluarkan suatu komponen tertentu dari bahan dengan bantuan pelarut. Salah satu metode ekstraksi adalah dengan teknik Microwave Assisted Extraction (MAE). Ekstraksi MAE merupakan teknik ekstraksi yang memanfaatkan radiasi gelombang mikro untuk memanaskan pelarut secara cepat dan efisien (Jain dkk., 2009). Metode MAE dapat membantu meningkatkan jumlah rendemen ekstrak kasar dalam waktu ekstraksi dan jumlah pelarut yang lebih rendah dibandingkan dengan metode ekstraksi konvensional (Langat, 2011). Panas radiasi gelombang mikro memanaskan dan menguapkan air sel bahan sehingga tekanan pada dinding sel meningkat mengakibatkan sel membengkak (swelling) dan tekanan tersebut mendorong dinding sel dari dalam, meregangkan, dan memecahkan sel tersebut (Calinescu dkk., 2001). Gelombang mikro 
mengurangi aktivitas enzimatis yang merusak senyawa target (Salas dkk., 2010). Rusaknya sel tumbuhan tersebut mempermudah senyawa target keluar dan terektraksi (Jain dkk. 2009).

Beberapa faktor yang mempengaruhi ekstraksi menggunakan teknik MAE adalah ukuran bahan, waktu, jenis pelarut, dan perbedaan konsentrasi. Kelarutan suatu zat ke dalam suatu pelarut sangat ditentukan oleh kecocokan sifat atau struktur kimia antara zat terlarut dengan pelarut, yaitu like disolves like (Hismath dkk. 2011 dalam Widarta dan Arnata, 2017). Pelarut etanol adalah pelarut polar sehingga pelarut ini sering digunakan untuk mengindentifikasi senyawa bioaktif (Arifin dkk. 2006).Perbedaan konsentrasi etanol dapat mengakibatkan perubahan polaritas pelarut sehingga mempengaruhi kelarutan senyawa bioaktif (Zhang dkk., 2009). Widarta dan Arnata (2015) melaporkan bahwa konsentrasi etanol berpengaruh terhadap komponen bioaktif, semakin tinggi konsentrasi etanol semakin tinggi juga komponen bioaktif yang dihasilkan. Handayani dkk. (2014) melaporkan juga bahwa semakin tinggi konsentrasi etanol maka rendemen ekstrak yang dihasilkan semakin tinggi, namun kadar polifenol mencapai optimum pada konsentrasi etanol tertentu.

Penelitian daun sirih merah telah dilakukan oleh Prayitno dkk (2017) menggunakan metode maserasi selama $3 \times 24$ jam dengan berbagai konsentrasi etanol dan didapatkan hasil bahwa konsentrasi etanol 90\% terbaik pada uji aktivitas antioksidan $\left(\mathrm{IC}_{50}\right)$ 82,71 ppm. Oleh karena itu diperlukan konsentrasi etanol yang tepat untuk mendapatkan aktivitas antioksidan tertinggi.

\section{Tempat dan Waktu}

Penelitian ini akan dilaksanakan di Laboratorium Analisis Pangan, Laboratorium Pengolahan Pangan Program Studi Ilmu dan
Teknologi Pangan Fakultas Teknologi Pertanian Universitas Udayana, Kampus Sudirman. Pelaksanaan penelitian ini dilakukan pada bulan Juli 2018 sampai dengan bulan Oktober 2018.

\section{Bahan dan Alat}

Bahan yang digunakan dalam penelitian ini adalah daun sirih merah (Piper crocatum Ruitz \& Pav), aquades, dan pelarut etanol (90\%, 80\%, 70\%, 60\%, dan 50\%) (Merck), $\mathrm{NaNO}_{2} 10 \%$ (Merck), $\mathrm{AlCl}_{3} 10 \%$ (Merck), Standar kuersetin (Sigma Aldrich), NaOH 1\% (Merck), Standar asam galat (Sigma Aldrich), DPPH (Sigma Aldrich), Reagen FolinCiocalteu (Merck), sodium karbonat (Merck), Air es.

Alat yang digunakan pada penelitian ini yaitu ayakan 60 mesh, microwave, rotary evaporator, oven, timbangan analitik (shimadzu), spektrofotometer (Genesys 10S UV-Vis), kertas whatman no.1, blender (Miyako), aluminium foil (Klin Pak), pipet micro, gelas ukur, gelas beker, loyang, waterbath, rak tabung reaksi, tabung reaksi (Pyrex), pipet volume, labu takar, dan pipet tetes.

\section{Rancangan Percobaan}

Penelitian ini menggunakan RAL (Rancangan Acak Lengkap) dengan perlakuan konsentrasi pelarut etanol dengan 5 taraf yaitu:

a. Konsentrasi etanol $50 \%$,

b. Konsentrasi etanol $60 \%$,

c. Konsentrasi etanol 70\%,

d. konsentrasi etanol $80 \%$,

e. konsentrasi etanol $90 \%$

Perlakuan ini diulang sebanyak tiga kali sehingga diperoleh 15 unit percobaan.

\section{Pelaksanaan Penelitian}

1. Pembuatan bubuk daun sirih merah

Daun sirih merah disortasi kemudian dicuci bersih. Pengeringan dilakukan dengan dioven pada suhu $40^{\circ} \mathrm{C}$ selama 24 Jam hingga 
kadar air $\leq 10 \%$. Daun sirih merah yang sudah kering diblender hingga halus dan diayak menggunakan ayakan 60 mesh sehingga didapat bubuk daun sirih merah yang siap diekstraksi (Nurfa'izin dkk. 2015 yang telah dimodifikasi).

2. Pembuatan ekstrak daun sirih merah

Proses ekstraksi daun sirih merah dilakukan dengan metode MAE. Bubuk daun sirih merah ditimbang sebanyak $15 \mathrm{~g}$ dan ditambahkan pelarut etanol sebanyak $150 \mathrm{ml}$ sesuai perlakuan. Perbandingan sampel dengan pelarut adalah 1:10. Selanjutnya sampel diletakkan didalam microwave dengan daya 450 Watt selama 8 menit. Sampel yang sudah diekstraksi disaring menggunakan alat penyaringan vakum dengan kertas whatman no.1 sampai diperoleh filtrat daun sirih merah, kemudian filtrat diuapkan dalam rotari evaporator vakum pada suhu $40^{\circ} \mathrm{C}$ dengan kecepatan $80 \mathrm{rpm}$ dan tekanan 100 mbar sampai diperoleh ekstrak kasar daun sirih merah (Nurfa'izin dkk. 2015 yang telah dimodifikasi).

\section{Variabel yang diamati}

Variabel yang diamati pada penelitian ini adalah Rendemen (Handayani dkk., 2016), total fenol (Garcia dkk., 2007), total flavonoid (Xu and Chang, 2007), dan aktivitas antioksidan ( $\mathrm{IC}_{50}$ ) (Sompong dkk., 2011).

\section{HASIL DAN PEMBAHASAN}

Hasil analisis rendemen, total fenol, total flavonoid dan aktivitas antioksidan bedasarkan $\mathrm{IC}_{50}$ dari ekstrak daun sirih merah dapat dilihat pada Tabel 1.

Tabel 1. Nilai rata-rata rendemen, total fenol, total flavonoid dan aktivitas antioksidan bedasarkan $\mathrm{IC}_{50}$ dari ekstrak daun sirih merah.

\begin{tabular}{ccccc}
\hline $\begin{array}{c}\text { Konsentrasi Etanol } \\
(\%)\end{array}$ & Rendemen $(\%)$ & $\begin{array}{c}\text { Total Fenol }(\mathrm{mg} \\
\text { GAE/g) }\end{array}$ & $\begin{array}{c}\text { Total flavonoid } \\
(\mathrm{mg} \mathrm{QE} / \mathrm{g})\end{array}$ & $\begin{array}{c}\text { IC50 } \\
(\mathrm{ppm})\end{array}$ \\
\hline P1 (50) & $22,65 \pm 0,40 \mathrm{~d}$ & $53,56 \pm 1,67 \mathrm{e}$ & $20,55 \pm 0,82 \mathrm{e}$ & $143,33 \pm 0,81 \mathrm{e}$ \\
P2 (60) & $23,21 \pm 0,06 \mathrm{~cd}$ & $66,27 \pm 2,09 \mathrm{~d}$ & $27,06 \pm 2,30 \mathrm{~d}$ & $133,70 \pm 0,80 \mathrm{~d}$ \\
P3 (70) & $23,73 \pm 0,13 \mathrm{c}$ & $80,27 \pm 1,37 \mathrm{c}$ & $34,92 \pm 1,00 \mathrm{c}$ & $125,40 \pm 1,20 \mathrm{c}$ \\
P4 ( 80) & $24,39 \pm 0,52 \mathrm{~b}$ & $92,97 \pm 1,27 \mathrm{~b}$ & $38,06 \pm 0,95 \mathrm{~b}$ & $113,32 \pm 1,90 \mathrm{~b}$ \\
P5 (90) & $25,17 \pm 0,29 \mathrm{a}$ & $106,00 \pm 1,49 \mathrm{a}$ & $46,98 \pm 1,00 \mathrm{a}$ & $81,61 \pm 1,73 \mathrm{a}$ \\
\hline
\end{tabular}

Keterangan: Huruf yang sama dibelakang nilai rata-rata pada kolom yang sama menunjukkan perlakuan berbeda tidak nyata $(\mathrm{P}>0,05)$. Nilai rata-rata diikuti dengan \pm standar deviasi.

\section{Rendemen Ekstrak Daun Sirih Merah}

Hasil sidik ragam menunjukan bahwa konsentrasi etanol berpengaruh sangat nyata $(\mathrm{P}<0,01)$ terhadap rendemen ekstrak daun sirih merah. Berdasarkan Tabel 1 Rendemen terendah terdapat pada konsentrasi etanol $50 \%$ yaitu $22,65 \%$ dan berbeda tidak nyata dengan konsentrasi etanol $60 \%$ yaitu $23,21 \%$. Rendemen tertinggi terdapat pada konsentrasi etanol $90 \%$ yaitu $25,17 \%$. Berdasarkan hal tersebut dapat dinyatakan bahwa semakin tinggi konsentrasi etanol maka akan meningkatkan rendemen ekstrak daun sirih merah.
Konsentrasi etanol mempengaruhi polaritas etanol yang digunakan. Kesesuaian polaritas pelarut dengan senyawa yang akan dilarutkan memaksimalkan ekstraksi yang dilakukan. Diem dkk. (2014) menyatakan bahwa semakin tinggi konsentrasi pelarut maka semakin besar kadar yang dapat tersari. Handayani dkk. (2014) melaporkan bahwa semakin tinggi konsentrasi etanol maka rendemen ekstrak yang dihasilkan akan semakin tinggi. Hal ini juga didukung oleh hasil penelitian Luginda dkk. (2018) yang melaporkan bahwa pada konsentrasi etanol 90\% menghasilkan rendemen tertinggi pada 
ekstrak daun beluntas dengan metode microwave.

\section{Total Fenol Ekstrak Daun Sirih Merah}

Hasil sidik ragam menunjukan bahwa konsentrasi etanol pada ekstrak daun sirih merah berpengaruh sangat nyata $(\mathrm{P}<0,01)$ terhadap kandungan total fenol. Berdasarkan Tabel 1 dapat dilihat bahwa total fenol tertinggi dihasilkan pada perlakuan konsentrasi etanol 90\% (P5) yaitu 106,00 mg GAE/g sedangkan hasil paling rendah diperoleh dengan perlakuan konsentrasi etanol 50\% (P1) yaitu 53,56 mg GAE/g. Hasil penelitian menunjukan bahwa semakin tinggi konsentrasi etanol maka semakin tinggi juga total fenol yang diperoleh pada ekstrak daun sirih merah. Hal serupa juga dilaporkan oleh prayitno dkk. (2017) bahwa konsentrasi etanol $90 \%$ menghasilkan total fenol tertinggi pada eksrak daun sirih merah menggunakan metode maserasi.

Etanol merupakan pelarut yang dapat melarutkan senyawa dari yang kurang polar hingga polar, salah satu senyawa yang dapat dilarutkan oleh etanol ialah senyawa fenolik. Etanol dapat melarutkan senyawa fenolik karena mampu mendegradasi dinding sel sehingga senyawa bioaktif lebih mudah keluar dari sel tanaman. Etanol memiliki gugus hidroksil yang dapat berikatan dengan gugus hidrogen dari gugus hidroksil senyawa fenolik yang menyebabkan peningkatan kelarutan senyawa fenolik dalam etanol. Perbedaan konsentrasi etanol dapat mempengaruhi kelarutan senyawa fenolik didalam pelarut (Prayitno dkk. 2016). Handayani dkk. (2014) menyatakan bahwa kesesuaian polaritas pelarut dengan bahan akan meningkatkan proses ektraksi pada bahan. Nisa dkk. (2014) menyatakan bahwa pada ekstraksi daun sirih merah, kenaikan konsentrasi etanol berbanding lurus dengan total fenol yang diperoleh.

\section{Total Flavonoid Ekstrak Daun Sirih Merah}

Hasil sidik ragam menunjukan bahwa konsentrasi etanol pada ekstrak daun sirih merah berpengaruh sangat nyata $(\mathrm{P}<0,01)$ terhadap kandungan total flavonoid. Berdasarkan Tabel 1 dapat dilihat bahwa total fenol tertinggi dihasilkan pada perlakuan konsentrasi etanol 90\% (P5) yaitu 46,98 mg QE/g sedangkan hasil paling rendah diperoleh dengan perlakuan konsentrasi etanol $50 \%$ (P1) yaitu $20,55 \mathrm{mg}$ QE/g. Hasil penelitian menunjukan bahwa semakin tinggi konsentrasi etanol maka semakin tinggi juga total flavonoid yang diperoleh pada ekstrak daun sirih merah. Hal serupa juga dilaporkan oleh prayitno dkk. (2017) bahwa konsenrasi etanol $90 \%$ menghasilkan total flavonoid tertinggi pada eksrak daun sirih merah menggunakan metode maserasi.

Harborne (1987) dalam Suryani dkk. (2015) menyatakan bahwa senyawa flavonoid terbagi menjadi beberapa jenis, tiap jenis flavonoid mempunyai kepolaran yang berbeda beda. Hasil penelitian menyatakan bahwa konsentrasi etanol yang meningkat akan meningkatkan total flavonoid. Purwanto dkk. (2014) menyatakan bahwa polaritas pelarut sangat mempengaruhi hasil ekstraksi bahan karena senyawa target yang akan diekstrak akan mudah larut pada tingkat polaritas yang sama.

\section{Aktivitas Antioksidan (IC50) Ekstrak Daun Sirih Merah}

Hasil sidik ragam menunjukan bahwa konsentrasi etanol pada ekstrak daun sirih merah berpengaruh sangat nyata $(\mathrm{P}<0,01)$ terhadap aktivitas antioksidan ( $\left.\mathrm{IC}_{50}\right)$. Berdasarkan Tabel 1 dapat dilihat bahwa $\mathrm{IC}_{50}$ tertinggi dihasilkan pada perlakuan konsentrasi etanol 90\% (P5) yaitu 81,61 ppm, sedangkan hasil paling rendah diperoleh dengan perlakuan konsentrasi etanol 50\% (P1) yaitu 143,33 ppm. Hasil penelitian menunjukan bahwa semakin tinggi 
konsentrasi etanol maka semakin tinggi juga aktivitas antioksidan yang diperoleh pada ekstrak daun sirih merah. Hal serupa juga dilaporkan oleh Prayitno dkk., (2017) bahwa konsentrasi etanol $90 \%$ menghasilkan aktivitas antioksidan berdasarkan $\mathrm{IC}_{50}$ tertinggi pada eksrak daun sirih merah menggunakan metode maserasi.

Inhibition Concentration $\left(\mathrm{IC}_{50}\right)$ yaitu kemampuan suatu senyawa dalam mereduksi sebesar 50\% senyawa radikal bebas. Nilai $\mathrm{IC}_{50}$ yang tertinggi menunjukan kemampuan antioksidan yang rendah, sebaliknya nilai $\mathrm{IC}_{50}$ yang rendah menunjukan kemampuan antioksidan yang tinggi. Aktivitas antioksidan dipengaruhi oleh meningkatnya fenol dan flavonoid pada bahan sehingga semakin tinggi total fenol dan flavonoid maka semakin tinggi juga aktivitas antioksidannya. Widarta dan Arnata (2017) menyatakan bahwa semakin tinggi konsentrasi pelarut maka aktivitas antioksidan yang dihasilkan juga semakin tinggi. Aktivitas antioksidan yang semakin tinggi dengan semakin meningkatnya konsentrasi etanol dapat disebabkan oleh kadar total fenolik dan total flavonoid yang juga semakin meningkat dengan meningkatkan konsentrasi etanol. Hal ini menunjukan adanya hubungan yang linier antara total fenolik dan flavonoid yang diperoleh dari ekstrak daun sirih merah dengan aktivitas antioksidan.

\section{KESIMPULAN DAN SARAN}

\section{Kesimpulan}

Berdsarkan dari hasil penelitian dapat disimpulkan sebagai berikut :

1. Konsentrasi etanol berpengaruh sangat nyata terhadap rendemen, total fenol, total flavonoid, dan aktivitas antioksidan ( $\left.\mathrm{IC}_{50}\right)$.

2. Konsentrasi etanol $90 \%$ merupakan perlakuan terbaik yang menghasilkan rendemen sebesar $25,17 \%$, total fenol 106,00 mg GAE/g ekstrak, total flavonoid
46,98 $\mathrm{mg}$ QE/g dan aktivitas antioksidan berdasarkan $\mathrm{IC}_{50}$ sebesar 81,61 ppm.

\section{Saran}

Perlu dilakukan penelitian lebih lanjut terkait pengaruh waktu ekstraksi MAE yang tepat untuk menghasilkam ekstrak daun sirih merah dengan aktivitas antioksidan yang optimum.

\section{DAFTAR PUSTAKA}

Arifin, H., N. Anggraini, D. Handayani dan R. Rasyid. 2006. Standarisasi ekstrak etanol daun Eugenia cumini Merr. Jurnal Sains Tek. Farmasi 11(2):88-93.

Calinescu, I., C. Ciuculescu, M. Popescu, S. Bajenaru, and G. Epure. 2001. Microwaves assisted extraction of active principles from vegetal material. Romanian International Conference on Chemistry and Chemical Engineering. 1(2):3-6.

Diem Do, Q. Artik, and E. Phoung. 2014. Effect of extraction solvent on total phenol content, total flavonoid content, and antioxidant activity of limnophilia arimatica. Journal Of Food And Drug Analisis. 2(2):296-302.

Garcia, C. A., G. Gavino, M. B. Mosqueda, P. Hevia, and V. C. Gavino. 2007. Correlation of tocopherol, tokotrienol, $\gamma$-oryzanol and total polyphenol content in rice bran with different antioxidant capacity assays. Food Chemistry 10(2):1230-1232.

Handayani, D., A. Mun'im dan A.S. Ranti. 2014. Optimation of green tea waste extraction using microwave assisted extraction to yield green tea extract. Traditional Medicine Journal 19(1):2935. 
Handayani, H., F. H. Sriherfyna, dan Yunianta. 2016. Ekstraksi antioksidan daun sirsak metode ultrasonic bath (kajian rasio bahan : pelarut dan lama ekstraksi). Pangan dan Agroindustri. 4(1):262-272.

Hendrayani, L., M. Lutfi, dan C. L. Hawa. 2015. Ekstraksi antioksidan daun sirih merah kering (Piper Crotatum) dengan metode pra-perlakuan ultrasonic assisted extraction (kajian perbandingan jenis pelarut dan lama ekstraksi). Bioproses Komoditas Tropis. 3(2):3335.

Jain, T., V. Jain, R. Pandey, A. Vyas, and S. S. Shukla. 2009. Microwave assisted extraction for phytoconstituents - an overview. Asian Journal Research Chemistry. 1(2):19-25.

Kanifah, U., M. Lutfi, dan B. Susilo. 2015. Karakterisasi ekstrak daun sirih merah (Piper Crocatum) dengan metode ekstraksi Non-Thermal berbantukan ultrasonik (kajian perbandingan jenis pelarut dan lama ekstraksi. Universitas Brawijaya. Malang. Jurnal Biopress Komoditas Tropis. 3(1):73-74.

Langat, M. K. 2011. Chemical Constituents of East European Forest Species. Book of Extented Extract, Kenya.

Luginda, R. A., B. Lohita., dan L. Indriani. 2018. Pengaruh variasi konsentrasi pelarut etanol terhadap kadar flavonoid total daun beluntas (Pluchea Indica (L.)Less) dengan metode microwaveassisted extraction (MAE). Universitas Pakuan. Bogor.

Nisa, G.K., W.A. Nugroho dan Y. Hendrawan. 2014. Extraction of red betel leaf (Piper crocatum) methods microwave assisted extraction. Jurnal Bioproses Komoditas Tropis 2(1):7278.

Nurfa'izn S., T. Puspitasari, S. Widiyanti, dan I. Hartati. 2015. Optimasi ekstraksi daun surian (Toonana Sureni Merr) sebagai bioinsektisida dengan menggunakan metode microwave assisted extraction. Universitas Wahid Hasyim. Semarang.

Prayitno, S. A., J. Kusnadi, and E. S. Murtini. 2016. Antioxidant activity of red betel leaves extract (Piper Crocatum Ruiz and Pav.) by difference concentration of solvents. department of food science and technology. University of Brawijaya, Malang. East Java. Indonesia.

Purwanto, A., A. N. Fajriyati, dan D. Wahyuningtyas. 2014. Pengaruh jenis pelarut terhadap rendemen dan aktivitas antioksidan dalam ekstrak minyak bekatul padi (rice bran oil). Ekuilibrium Journal 13(1): 29-34.

Salas, P. G., M. S. Aranzazu, S. C. Antonio, and F. G. Alberto. 2010. Phenoliccompound-extraction systems for fruit and vegetable samples. molecules, 1(5):8823-8826.

Sompong R, S. Siebenhandl-Ehn, G. Linsberger-Martin, E. Berghofer. 2011. Physicochemical and antioxidative properties of red and black roce varieties from Thailand, China, and srilanka. J. Food Chem. 124:132-140

Steel, R.G.D. dan J.H. Torrie. 1993. Prinsip dan prosedur statistika suatu pendekatan biometrik. Penerjemah B. Sumantri. PT. Gramedia Pustaka, Jakarta. 
Sudewo, B. (2005). Basmi penyakit dengan sirih merah. Jakarta: Penebar Swadaya.

Sulistiyani, Arniputri, dan B. Retna. 2007. Identifikasi komponen utama minyak atsiri sirih merah. Biodiversitas. 8(2):136-137.

Widarta, I.W.R dan I.W. Arnata. 2017. Ekstraksi komponen bioaktif daun alpukat dengan bantuan ultrasonik pada berbagai jenis dan konsentrasi pelarut. Jurnal AGRITECH 37(2):148-157.

$\mathrm{Xu}$, B. J. and S. K. C. Chang. 2007. A comparative study on phenolic profiles and antioxidant activities of legumes as affected by extraction solvents. Journal Food Science. 72(2):161-166.

Zhang, L., Y. Shan, K. Tang, and R. Putheti. 2009. Ultrasound-assited extraction flavonoid of lotus (Nelumbo nuficera Gaertn) leaf and evaluation of its antifatigue activity. International Journal of Phisical Science 4(8):418-422. 